\title{
Relationship of carbon availability in estuarine phytoplankton to isotopic composition
}

\author{
Marilyn L. Fogel ${ }^{1}$, Luis A. Cifuentes ${ }^{2}$, David J. Velinsky ${ }^{1,3}$, Jonathan H. Sharp ${ }^{3}$ \\ ${ }^{1}$ Carnegie Institution of Washington, Geophysical Laboratory, Washington, D.C. 20015, USA \\ ${ }^{2}$ Department of Oceanography, Texas A \& M University, College Station, Texas 77843, USA \\ ${ }^{3}$ College of Marine Studies, University of Delaware, Lewes, Delaware 19958, USA
}

\begin{abstract}
The carbon isotope ratio of particulate carbon in an estuary can vary by at least $10 \%$ throughout the year. In this study, 2 periods of high primary productivity are compared from data collected in both spring and summer of 1987 and 1988 from the Delaware Estuary (USA). In spring, particulate carbon isotopic compositions $\left(\delta^{13} \mathrm{C}\right.$ ) were the most positive (up to $-17 \%$ ), whereas in summer the values were the most negative (to $-32 \%$ ). Equations calculating the $\mathrm{CO}_{2}$ concentrations within algal cells were used to show that growth of phytoplankton, especially in spring, may be limited by the availability of dissolved carbon dioxide, $\mathrm{CO}_{2(d)}$. An alternative hypothesis for the enrichment of ${ }^{13} \mathrm{C}$ in diatoms from spring blooms includes the possibility that a mechanism for active bicarbonate accumulation is induced during high primary productivity. Similarly, a model is developed for

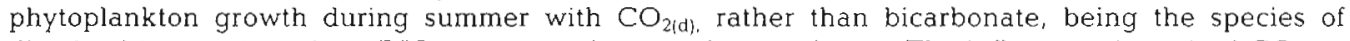
dissolved inorganic carbon (DIC) transported across the membrane. The influence of respired $\mathrm{CO}_{2}$ on the isotopic composition of total DIC in summer is also calculated to explain the differences in isotopic compositions of particulate carbon. The demand for $\mathrm{CO}_{2(d)}$ during periods of high primary productivity limits its availability to phytoplankton. This demand could easily be met by the induction of an active transport system for concentrating DIC, which could explain some of the variability in $\delta^{13} \mathrm{C}$ of particulate carbon in estuaries and oceans.
\end{abstract}

\section{INTRODUCTION}

Nitrogen is traditionally thought to be the limiting nutrient in marine systems (e.g. Ryther \& Dunstan 1971, Carpenter \& Capone 1983). Recently, there has been interest in the possibility that phosphorus may limit nearshore and oceanic primary productivity instead of, or in addition to, nitrogen (e.g. Smith 1984 , Hecky \& Kilham 1988). Under eutrophic conditions or during periods of high primary productivity, however, it is possible that nutrients other than nitrogen or phosphorus limit the growth of phytoplankton. The possibility of iron limitation has been posed for many years (Harvey 1938) and has been reconsidered recently (e.g. Martin et al. 1989). In contrast, carbon is often considered to be available in limitless supply for photosynthetic fixation by marine phytoplankton, because the concentration of total dissolved inorganic carbon (DIC) in estuarine water is 1 to 2 orders of magnitude greater than that of inorganic nitrogen or phosphorus.
Total DIC concentrations, however, can be misleading measures of the availability of carbon for phytoplankton, because inorganic carbon exists as several chemical species in estuarine waters:

$$
\mathrm{CO}_{2(\mathrm{~g})} \Leftrightarrow \mathrm{CO}_{2(\mathrm{~d})} \Leftrightarrow \mathrm{H}_{2} \mathrm{CO}_{3(\mathrm{~d})} \Leftrightarrow \mathrm{HCO}_{3}{ }^{-} \Leftrightarrow \mathrm{CO}_{3}{ }^{2-}
$$

where $\mathrm{CO}_{2(\mathrm{~g})}$ and $\mathrm{CO}_{2\{\mathrm{~d} \mid}$ are gaseous and dissolved $\mathrm{CO}_{2}$ respectively. At typical $\mathrm{pH}$ values for estuarine waters ( 7.5 to 8.5), the dominant inorganic carbon species is bicarbonate $\left(\mathrm{HCO}_{3}{ }^{-}\right)$(Skirrow 1975). Phytoplankton and other aquatic plant species, however, utilize $\mathrm{CO}_{2(\mathrm{~d})}$ during enzymatic fixation, rather than bicarbonate (Cooper et al. 1969). It is, therefore, important to understand the distribution of the various inorganic carbon species to assess carbon limitation during primary productivity.

In the past $15 \mathrm{yr}$, an intense effort has been made to understand DIC-concentrating mechanisms in aquatic plants (see Lucas \& Berry 1985, for a recent review). 
When plants grow in waters with low concentrations of DIC, photosynthetic rates are kept maximal by the organisms' ability to concentrate DIC (i.e. either $\mathrm{CO}_{2|d\rangle}$ or $\mathrm{HCO}_{3}{ }^{-}$) inside the cell by an energy-dependent mechanism. The enzyme, carbonic anhydrase, converts the accumulated bicarbonate to $\mathrm{CO}_{2(d)}$, which is then fixed by ribulose 1,5-bisphosphate (RuBP) carboxylase. This mechanism has been especially important in the success of certain species of submerged aquatic vegetation (e.g. Hydrilla sp.; Van et al. 1976) that thrive in estuaries with high $\mathrm{pH}$ surface waters $(\mathrm{pH}=9.0)$, where the concentration of $\mathrm{CO}_{2(\mathrm{~d})}$ is less than $1 \mu \mathrm{M}$.

The relationship between the concentration of $\mathrm{CO}_{2(\mathrm{~d})}$ and organic carbon produced during photosynthesis by different algal species has been defined with carbon isotope ratios at the natural abundance level (Vogel 1980, Estep 1984). Stable carbon isotope ratios $\left(\delta^{13} \mathrm{C}\right)$ of algal organic carbon, for example, are inversely proportional to the concentration of both available DIC and $\mathrm{CO}_{2(d)}$. At lower levels of DIC, algal $\mathrm{C}$ has essentially the same $\delta^{13} \mathrm{C}$ values as the dissolved $\mathrm{CO}_{2}$, whereas at higher concentrations, the carbon isotope composition of organic $\mathrm{C}$ is enriched in the light isotope, ${ }^{12} \mathrm{C}$, because of biochemical kinetic isotope fractionation (e.g. Vogel 1980, Estep 1984).

Primary fractionation of carbon isotopes occurs during $\mathrm{CO}_{2}$ fixation by RuBP carboxylase. A carbon isotope fractionation of $-29.4 \%$ relative to $\mathrm{CO}_{2(\mathrm{~d})}$ was determined by in vitro experiments (Roeske \& O'Leary 1984, Guy et al. 1987). In theory, if the isotopic ratio of $\mathrm{CO}_{2(\mathrm{~d})}$ in seawater has a $\delta^{13} \mathrm{C}$ value of about $-7 \%$ (Kroopnick et al. 1970, Mook et al. 1974), algal cells growing in a large excess of total DIC should have $\delta^{13} \mathrm{C}$ values of about -36 . The carbon isotopic compositions of suspended particulate material derived primarily from phytoplankton from various estuaries, however, have been found to be considerably more positive $\left({ }^{13} \mathrm{C}=-16\right.$ to -28 ; see Fry \& Sherr 1984 for review). A. simple assumption has been that $\mathrm{CO}_{2(\mathrm{~d})}$ enters these algae by diffusion (O'Leary 1988), which would result in variability of the $\delta^{1.3} \mathrm{C}$ value depending on whether carboxylation or diffusion was the rate-limiting step of carbon fixation.

Alternatively, the diminished expression of carbon isotopic fractionation could be caused by the operation of an active DIC-concentrating mechanism in the dominant members of the phytoplankton community. In order to trace an alga's ability to concentrate DIC against a concentration gradient, Sharkey \& Berry (1985) measured the difference, or fractionation, of stable carbon isotopes between $\mathrm{CO}_{2(\mathrm{~d})}$ and algal $\mathrm{C}$ in cultures grown under high and low $\mathrm{CO}_{2(\mathrm{~d})}$ conditions. Isotopic fractionation decreased dramatically to $-4.1 \%$ at low $\mathrm{CO}_{2(d)}$ concentrations $(0.03 \%)$, when algal cells were actively transporting bicarbonate. At high concentrations of $\mathrm{CO}_{2(d)}(5 \%)$, however, the mechanism for DIC transport was suppressed, and the isotopic fractionation increased to $-27.9 \%$, relative to the isotopic composition of the $\mathrm{CO}_{2}$. The increased fractionation occurred because of the large carbon isotopic fractionation that is associated with $\mathrm{CO}_{2(\mathrm{~d})}$ fixation by RuBP carboxylase.

It has been proposed that the variability and enrichment of ${ }^{12} \mathrm{C}$ in phytoplankton $\mathrm{C}$ are influenced by a number of factors including temperature, species composition, $\mathrm{DIC}$ and $\mathrm{CO}_{2(\mathrm{~d})}$ concentrations, and varying carbon isotopic ratios of the available DIC (Sackett et al. 1964, Lewan 1986, Rau et al. 1989). In this paper, we report on variability of the carbon isotope ratios $(>10 \%)$ of phytoplankton from 2 high-productivity periods in the Delaware Estuary, USA. We will demonstrate that the above factors could not explain such large variations. Instead, we argue that phytoplankton were most likely actively transporting and accumulating bicarbonate during the spring bloom, and $\mathrm{CO}_{2(\mathrm{~d})}$ during the period of high productivity in summer.

\section{STUDY AREA}

The Delaware Estuary is a coastal plain estuary that is strongly influenced by the large urban population center in the Greater Philadelphia Metropolitan area (Fig. 1). The biogeochemistry of the estuary has been described in detail previously (Sharp et al. 1982, 1984, 1986. Church 1986, Culberson 1988, Sharp 1988). Pennock (1985) and Pennock \& Sharp (1986) described phytoplankton dynamics of the estuary. In spring, a bloom comprised primarily of the diatom Skeletonema costatum dominates the mid-Bay region of the estuary. During summer, a series of high-productivity periods can occur that contain a mixture of species, but are dominated by naked flageilates. Light is thought to be the principal limiting factor in the upper estuary throughout the year; in spring and summer, nitrogen or phosphorus limits productivity in the lower bay (Pennock 1985, Pennock \& Sharp 1986, Lebo \& Sharp 1992).

\section{METHODS}

A series of 24 cruises from Trenton, New Jersey, to the mouth of the Delaware Estuary were undertaken from June 1986 to September 1988 (see Lebo et al. 1990, for summary of data). Along the spine of the estuary, 26 stations were sampled at roughly $10 \mathrm{~km}$ intervals (see Cifuentes et al. 1989). At each station physical, chemical, biological, and isotopic parameters were measured, to provide an understanding of many 


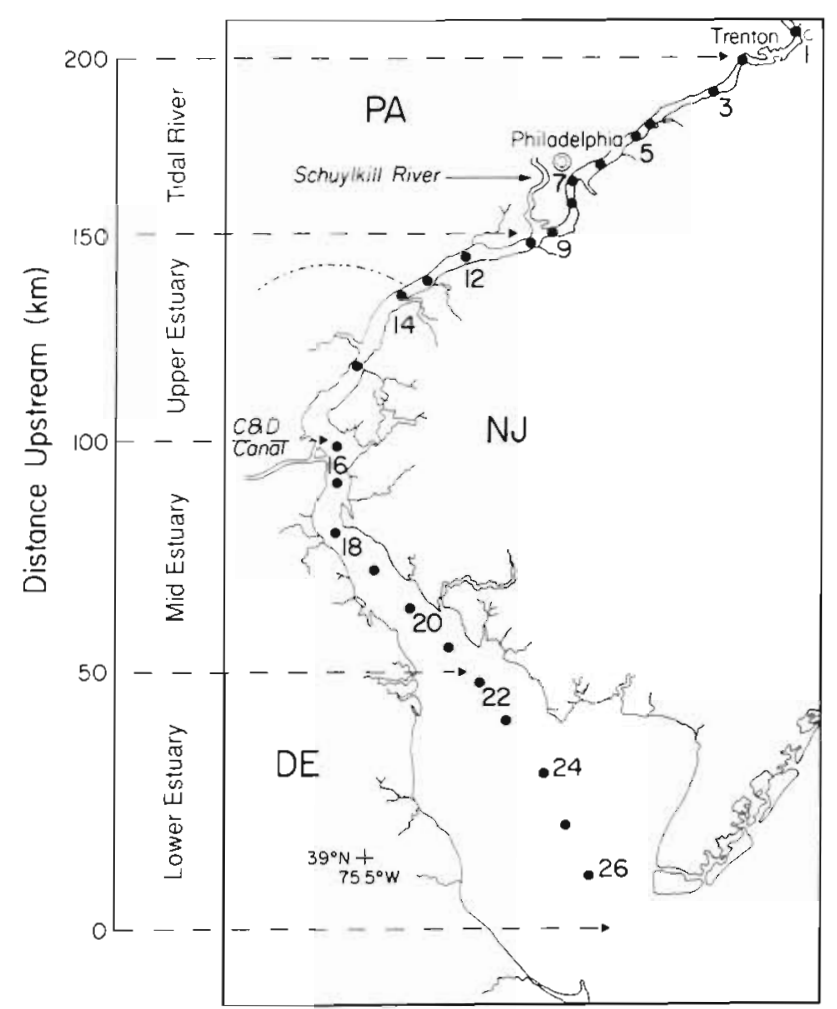

Fig. 1. The Delaware Estuary. Samples from 24 cruises were collected along the longitudinal axis of the estuary. Data are often averaged in terms of the middle (distance upstream: 50 to $100 \mathrm{~km}$; salinity 1 to $15 \%$; Stns 16 to 21 ) and lower (distance upstream: 0 to $50 \mathrm{~km}$; salinity 15 to $30 \%$; Stns 22 to 26$)$ regions of the estuary

of the possible factors influencing the biogeochemistry of the estuary. Data from cruises reported in this paper were taken from 3 spring cruises (22-23 March 1987 6-7 April 1987; 23-24 March 1988) and 2 summer cruises (25-26 June 1987; 27-28 July 1987). These data are compared with that collected during a fall cruise (30 September-1 October 1987).

Total DIC was determined by injecting an aliquot of water into a dilute phosphoric acid solution and measuring the evolved $\mathrm{CO}_{2(g)}$ in a flow-through system with a nondispersive infrared detector (Horiba PIR5000 ). The average relative standard deviation from 4 replicate injections of samples was about $\pm 3 \%$. Primary productivity was measured by ${ }^{14} \mathrm{C}$-uptake using the method of Eppley \& Sharp (1974), as modified by Pennock \& Sharp (1986). Samples were incubated for $24 \mathrm{~h}$ under simulated in situ conditions with a light attenuation series on the deck of the ship. Volume productivity ( $\mu \mathrm{M} \mathrm{C} \mathrm{d} \mathrm{d}^{-1}$ ) measurements were taken from the maximum productivity measured.

Particulate matter (seston) for carbon isotope analysis was collected by pressure filtration on $1 \mu \mathrm{m}$
Nuclepore polycarbonate filters (142 $\mathrm{mm}$ diameter). Samples were rinsed from filters with distilled water, concentrated by centrifugation, and then dried at $40^{\circ} \mathrm{C}$. Approximately $40 \mathrm{mg}$ of dried seston was then loaded into a preheated quartz tube $6 \mathrm{~mm}$ outer diameter) with reagent-grade $\mathrm{Cu}$ and $\mathrm{CuO}$. The tube was sealed under vacuum and combusted at $900^{\circ} \mathrm{C}$ for $1 \mathrm{~h}$. Tubes were cooled slowly $\left(0.6^{\circ} \mathrm{C} \mathrm{min} \mathrm{m}^{-1}\right.$ from 700 to $500^{\circ} \mathrm{C}$ ) following combustion. Resulting gases were distilled cryogenically in a vacuum line. Separated $\mathrm{CO}_{2}$ was analyzed on a triple collector isotope ratio mass spectrometer (Nuclide 6-60-RMS).

Isotope ratios of the total DIC were determined by the method of Hassan (1980). In brief, inorganic carbon was precipitated as $\mathrm{SrCO}_{3}$ after the addition of $\mathrm{SrCl}_{2}$ in concentrated $\mathrm{NH}_{4} \mathrm{OH}$. Precipitated $\mathrm{SrCO}_{3}$ was collected by filtration under an $\mathrm{N}_{2}$ atmosphere and rinsed exhaustively with distilled water until the effluent reached neutrality. An aliquot of Sr precipitate (10 to $100 \mathrm{mg}$ ) was reacted with $100 \%$ phosphoric acid. The evolved $\mathrm{CO}_{2}$ was purified via cryogenic distillation.

Carbon isotope ratios are expressed as follows:

$$
\delta^{13} \mathrm{C}=\left[\frac{\left({ }^{13} \mathrm{C} /{ }^{12} \mathrm{C}\right)_{\text {sample }}}{\left({ }^{13} \mathrm{C} /{ }^{12} \mathrm{C}\right)_{\text {standard }}}-1\right] \times 10^{3}
$$

The standard for $\delta^{13} \mathrm{C}$ analysis is the PeeDee belmenite limestone that has been assigned a value of $0.0 \%$. Replicate analysis of particulate samples or $\mathrm{SrCO}_{3}$ resulted in isotopic values with a standard deviation of $\pm 0.2 \%$.

\section{RESULTS AND DISCUSSION}

\section{Carbon isotopic compositions}

The Delaware Estuary has a pronounced spring bloom with high productivity and large phytoplankton biomass accumulation that occurs predictably from early March through mid-April (Pennock 1985, Pennock \& Sharp 1986). This spring bloom is located primarily between about 50 and $75 \mathrm{~km}$ from the mouth of the estuary. In summer, there is high productivity in the lower estuary, but very low phytoplankton biomass (Pennock 1985, Pennock \& Sharp 1986; Fig. 2).

Particulate carbon that has been shown to be derived originally from phytoplankton (Cifuentes et al. 1988) had extremely variable isotopic compositions. For example, average carbon isotopic ratios of seston from the mid (salinity range: 1 to $15 \mathrm{ppt}$ ) and lower (salinity range: 15 to $30 \mathrm{ppt}$ ) bay differed by $10 \%$ between spring in 1987 and 1988 and summer in 1987 (Fig. 3). Individual samples had $\delta^{13} \mathrm{C}$ values as negative as $-31 \%$ in summer to values as positive as $-17.9 \%$ in 

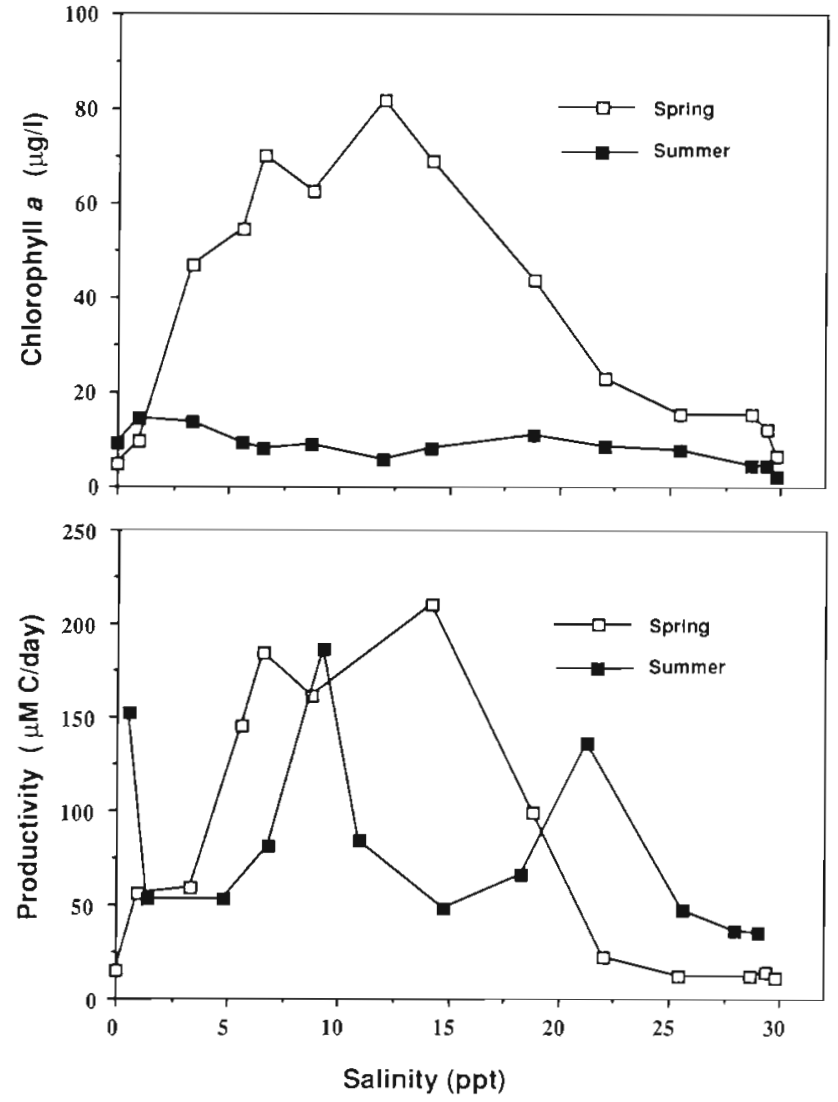

Fig. 2. Chlorophyll a (upper) and productivity (lower) as functions of salinity in the Delaware Estuary during spring (22-23 March) and summer (25-26 June) 1987. In spite of high productivity in summer, the standing stock of phytoplankton is low, most likely as a result of grazing

spring (6-7 April 1987). Productivity rates in spring were more variable, but an average value was only slightly higher than that in summer (Fig. 3). A previous study has shown that carbon isotopic compositions of seston within one bloom correlated positively with primary productivity, but this simplified relationship occurred only in spring (Cifuentes et al. 1988). In this study, we found no overall correlation of $\delta^{13} \mathrm{C}$ with primary productivity.

To explain the cause(s) of the large variation in $\delta^{13} \mathrm{C}$ of particulate carbon, the $\delta^{13} \mathrm{C}$ of DIC, which can control the $\delta^{13} \mathrm{C}$ of phytoplankton, was investigated. In a study by Spiker \& Schemel (1979), high rates of primary productivity resulted in more positive $\delta^{13} \mathrm{C}$ of DIC. The shift in the isotopic composition of DIC occurred as the light isotope of $\mathrm{C}$ was preferentially incorporated into organic matter During conservative mixing (i.e no photosynthesis or respiration), the isotopic composition of DIC in the Delaware Estuary should reflect mixing of riverine DIC with a $\delta^{13} \mathrm{C}$ of ca $-11 \%$ and marine DIC with a $\delta^{13} \mathrm{C}$ of $\mathrm{ca} 0.0 \%$

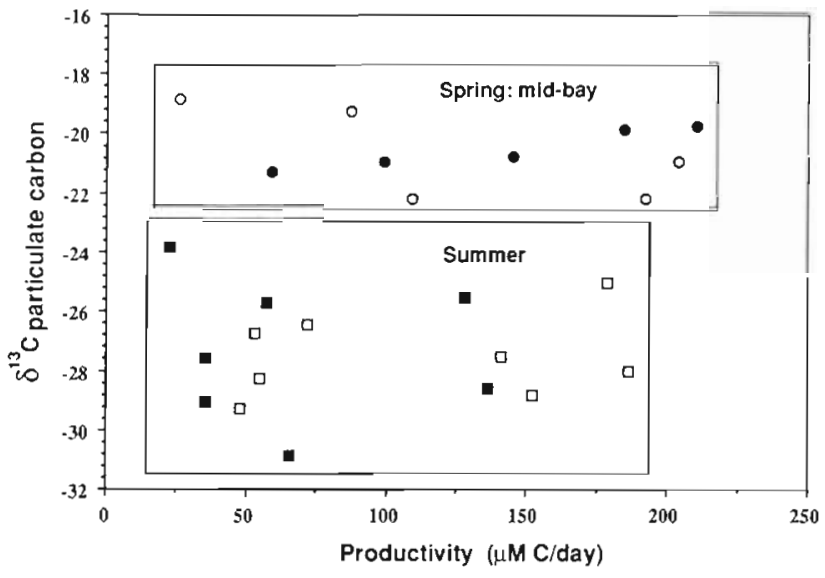

Fig. 3. Carbon isotopic composition $\left(\delta^{13} \mathrm{C}, \%\right)$ of particulate carbon in spring and summer as a function of productivity in the water column at corresponding times. The spring values occur primarily in the high productivity maxima in mid-bay (salinity 1 to 15\%o). (•) Samples collected in March 1987; (o) samples collected in April 1988. For the summer 1987 values: (a) samples were collected from the lower bay (salinity $15-30 \%$ ) ; ( ) samples collected at mid-bay

(Fogel et al, 1988). Conservative mixing curves for the $\delta^{13} \mathrm{C}$ of DIC during spring and summer cruises are compared with the actual data (Fig. 4). These curves are nonlinear, because they are derived from both endmember $\delta^{13} \mathrm{C}$ values and actual DIC concentrations. The data exhibit nonconservative behavior; presumably photosynthesis and mineralization altered the $C$ isotopic composition of the total inorganic $C$ pool. These deviations from theoretical values occurred near or slightly down bay from the areas of maximum phytoplankton productivity, especially during summer and fall (Lebo et al. 1990). The spring bloom does not have high bacterial activity, unlike the summer when bacteria closely track the phytoplankton (Coffin \& Sharp 1987). Therefore, in spring, the actual $\delta^{13} \mathrm{C}$ of DIC is isotopically heavier because of photosynthetic uptake, whereas in summer both uptake and remineralization of $\mathrm{CO}_{2}$ affected isotopic compositions.

The large differences $(10 \%)$ in the isotopic composition of the particulate matter cannot be explained by the $\delta^{13} \mathrm{C}$ of the DIC alone. The DIC in spring at the location of the most positive $\delta^{13} \mathrm{C}$ values (around $20 \mathrm{ppt}$ salinity) was only $1 \%$ heavier than the DIC in summer in the area of the most negative $\delta^{13} \mathrm{C}$ (around 25 to $30 \mathrm{ppt}$ salinity). The maximum difference in the $\delta^{13} \mathrm{C}$ of $\mathrm{DIC}$ was $3.5 \%$, the most positive value being measured at only 1 station in the lower bay during March 1987. The $\delta^{13} \mathrm{C}_{\text {DIC }}$ in the regions corresponding to both spring and summer productivity maxima, however, ranged from -1 to $-3 \%$. Therefore, part, but not all, of the difference in the $\delta^{13} \mathrm{C}$ of particulate matter can be explained by the isotopic composition of inorganic carbon available to the 

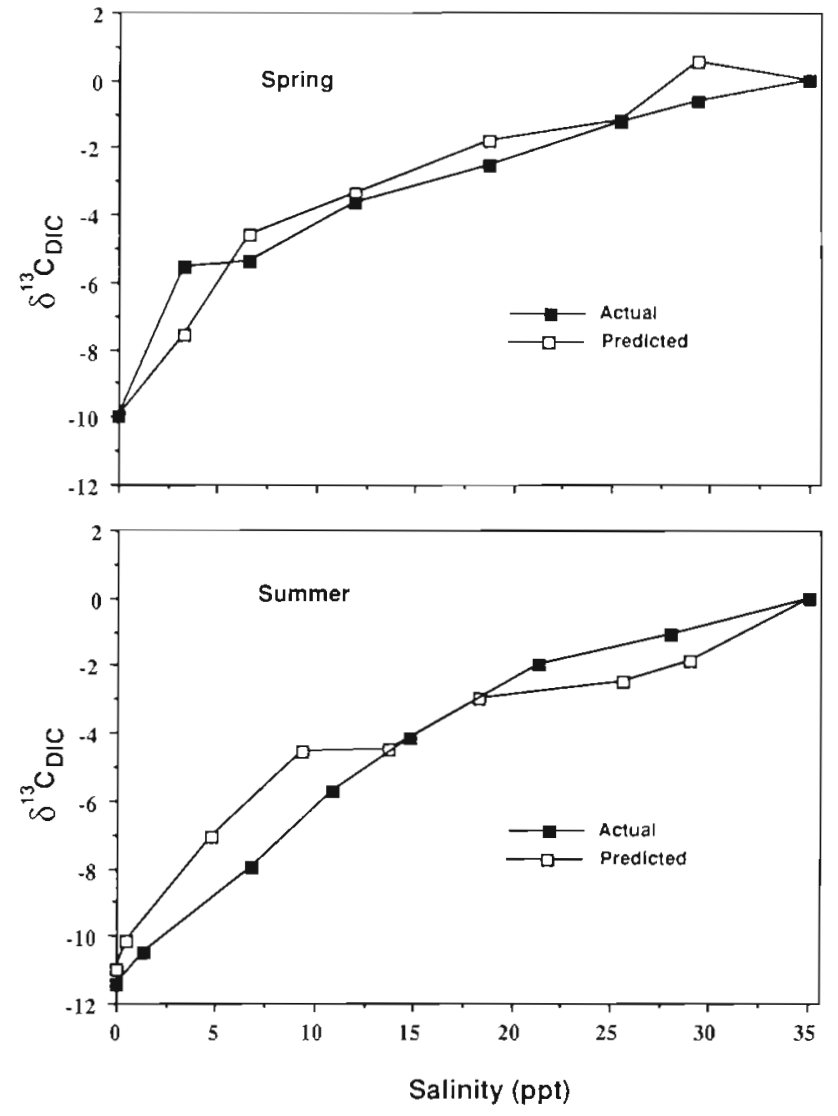

Fig. 4. Isotopic composition $\left(\delta^{13} \mathrm{C}, \%\right)$ of total dissolved inorganic carbon (DIC) as a function of salinity, showing conservative mixing lines (predicted), calculated with the equations given in Spiker \& Schemel (1979), and actual DIC isotope data from the spring (upper) and summer (lower) cruises. The conservative mixing line was calculated with endmembers (riverine and marine) and the actual salinities and DIC concentrations measured along the spine of the estuary

phytoplankton. Isotopic fractionation during carbon uptake may have a greater influence.

\section{Carbon isotopic fractionation}

The species of DIC that is fixed enzymatically by phytoplankton is $\mathrm{CO}_{2(\mathrm{~d})}$ (Cooper et al. 1969). Therefore, isotopic fractionations should be calculated relative to this $\mathrm{C}$ species. Isotopic fractionation during photosynthesis is defined as follows:

$$
\Delta=\delta^{13} \mathrm{C}_{\text {particulate }} \mathrm{c}^{-} \delta^{13} \mathrm{C}_{\mathrm{CO}_{2 \mid \mathrm{d}}}
$$

This equation is a simplified version of that presented in O'Leary (1988) and yields values for $\Delta$ that are close approximations. To estimate the isotopic composition

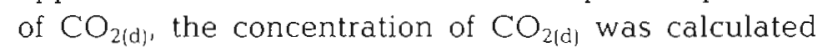
from measured total DIC from our salinity, tempera- ture, and $\mathrm{pH}$ data, and the ionization constants from Millero (1979) (see Whitfield \& Turner 1986). After the speciation of the DIC is determined, the equilibrium isotope fractionation between $\mathrm{HCO}_{3}^{-}$and $\mathrm{CO}_{2}$ must be incorporated (Mook et al. 1974). These calculations assume that the bicarbonate- $\mathrm{CO}_{2(\mathrm{~d})}$ system is in equilibrium and that the concentration of $\mathrm{CO}_{3}{ }^{2-}$ is negligible at the $\mathrm{pH}$ of estuarine waters. The $\mathrm{pH}$ ranged from 7.0 to 8.4 in the mid to lower Delaware Estuary during the course of our study (Lebo et al. 1990). When the $\delta{ }^{13} \mathrm{C}$ values of $\mathrm{CO}_{2(\alpha)}$ rather than total DIC were used to calculate fractionations during blooms in the Delaware Estuary, isotope fractionations in spring $(\Delta=-7$ to $-11 \%)$ were smaller than those in summer $(\Delta=-13$ to $-18 \%$; Table 1 ).

Equations have been developed by Farquhar and others (e.g. Farquhar et al. 1982) to model the relationship of the isotope fractionation, $\Delta$, to $\mathrm{CO}_{2}$ concentrations both internal and external to plant cells. Internal $\mathrm{CO}_{2}$ concentration measurements are difficult to determine experimentally. Moreover, the concentration of $\mathrm{CO}_{2}$ external to the plant cannot always be measured realistically over the growing season of a plant. With equations developed by Farquhar and others, carbon isotope ratios and fractionations can be used to infer gas exchange characteristics of photosynthetic organisms. Their model is valid for plants that fix $\mathrm{CO}_{2}$ initially with RuBP carboxylase and assumes $\mathrm{CO}_{2}$ enters only by diffusion:

$$
\Delta=a+c_{1} / C_{a} \times(b-a)
$$

where $a=$ isotope fractionation during diffusion of $\mathrm{CO}_{2}$ in air or water; $c_{\mathrm{i}} / c_{\mathrm{a}}=\left[\mathrm{CO}_{2}\right]_{\text {internal }} /\left[\mathrm{CO}_{2}\right]_{\text {externali }}$ and $b=$ the enzymatic fractionation during carboxylation. The isotopic effect during diffusion of $\mathrm{CO}_{2}$ is negligible in water, and a value of $-27 \%$, which is used for $b$, is the combined isotope fractionation for fixation by both RuBP and PEP carboxylases (Farquhar et al. 1982).

This type of calculation can be used to estimate whether diffusion of $\mathrm{CO}_{2(d)}$ can supply enough carbon for phytoplankton at any one time. As examples, we have calculated $c_{1} / c_{a}$ for the 2 extreme fractionations measured in spring blooms and summer productivity maxima, in addition to a more typical fractionation calculated during lower productivity in the fall (Table 2). With a representative value of $20 \mu \mathrm{M} \mathrm{CO}_{2\{\mathrm{~d}\}}$ for surface waters, the concentration of internal $\mathrm{CO}_{2(d)}$ was determined. Even when productivity occurred at a moderate rate $\left(40 \mu \mathrm{M} \mathrm{C} \mathrm{d}{ }^{-1}\right)$, the $\left[\mathrm{CO}_{2}\right]_{\text {internal }}$ was always much less than $\left[\mathrm{CO}_{2}\right]_{\text {external }}$. Residence times of $\mathrm{CO}_{2(\mathrm{~d})}$ inside phytoplankton are low, especially during the spring bloom. Based on the low $c_{1} / c_{a}$ value and the short residence time, the growth of diatoms in spring most likely is limited by $\mathrm{CO}_{2(d)}$ availability. 
Table 1. Isotope fractionation $(\Delta)$ from the Delaware Bay in spring and summer. Particulate carbon $\delta^{13} \mathrm{C}$ and productivity were averaged from the individual values of 3 to 5 samples collected along each transect. Samples for measurement of $\delta^{13} \mathrm{C}$ of particulate and dissolved inorganic carbon and $\left[\mathrm{CO}_{2}\right]$ were taken from the midpoint of the area in the estuary. All spring values in this table were from midbay

\begin{tabular}{|c|c|c|c|c|c|c|}
\hline Cruise date & $\begin{array}{c}\delta^{13} \mathrm{C}_{\text {seston }} \\
(\%)\end{array}$ & $\begin{array}{c}\delta^{13} \mathrm{C}_{\text {told }]} \\
(\%)\end{array}$ & $\begin{array}{l}\text { Temp. } \\
\left({ }^{\circ} \mathrm{C}\right)\end{array}$ & $\begin{array}{l}\mathrm{CO}_{2 \mid(d)} \\
(\mu \mathrm{M})\end{array}$ & $\begin{array}{c}\delta^{13} \mathrm{C}_{\mathrm{CO}_{2 \mid \mathrm{d}}{ }^{\mathrm{a}}} \\
(\% \circ)\end{array}$ & $\begin{array}{l}\Delta^{\mathrm{b}} \\
(\% \mathrm{o})\end{array}$ \\
\hline \multicolumn{7}{|l|}{ Spring } \\
\hline Mar 1987 & -20.2 & -1.2 & 6 & 19.4 & -12.4 & -7.8 \\
\hline Apr 1987 & -21.4 & 0.5 & 9 & 16.6 & -10.4 & -11.0 \\
\hline Apr 1988 & -20.3 & -2.6 & 10 & 14.2 & -13.7 & -6.6 \\
\hline Average & -20.6 & -1.1 & 8.3 & 16.7 & -12.2 & -8.5 \\
\hline \multicolumn{7}{|l|}{ Summer } \\
\hline Jun 1987 Mid-bay & -27.8 & -2.5 & 25 & 22.7 & -11.6 & -16.2 \\
\hline Jun 1987 Lower bay & -29.5 & -1.9 & 21 & 20.2 & -11.4 & -18.1 \\
\hline Jul 1987 Mid-bay & -26.6 & -3.1 & 29 & 11.8 & -11.9 & -14.7 \\
\hline Jul 1987 Lower bay & -25.0 & -2.2 & 25 & 14.1 & -11.6 & -13.4 \\
\hline Average & -27.2 & -2.4 & 25 & 17.2 & -11.6 & -15.6 \\
\hline
\end{tabular}

The higher $c_{\mathrm{i}} / C_{\mathrm{a}}$ from summer relative to the low $c_{1} / c_{a}$ from spring may be indicative of real differences in the physiology of the different phytoplankton species during high productivity. Two processes could affect the apparent $c_{\mathrm{i}} / c_{2}$, which are directly related to isotope fractionation. First, during periods of intense primary productivity, the organisms may respond by initiating an active transport system for $\mathrm{HCO}_{3}{ }^{-}$or $\mathrm{CO}_{2(d)}$. Second, when bacterial activity, i.e. respiration and nutrient regeneration, is especially accelerated in summer (Coffin \& Sharp 1987), $\mathrm{CO}_{2(\mathrm{~d})}$ may be released at rates greater than than those associated with invasion into cells or evasion to the atmosphere of $\mathrm{CO}_{2(g)}$. The nonconservative behavior of $8^{13} \mathrm{C}_{\mathrm{DIC}}$ in the estuary is evidence that equilibrium may not be attained.

\section{Active vs diffusive transport of inorganic carbon into algal cells}

Active transport of $\mathrm{HCO}_{3}{ }^{-}$results in less isotopic fractionation during photosynthesis than does diffusive transport of $\mathrm{CO}_{2(\mathrm{~d})}$ (Sharkey \& Berry 1985; Fig. 5), be- cause, theoretically, isotope fractionation decreases as phytoplankton cells become 'closed', rather than 'open'. An analogous situation may occur during spring when the measured fractionations $(\Delta=-7$ to -11$)$ are considerably less than the maximal theoretical $\Delta(-29)$, which can be attained only at high concentrations when $\mathrm{CO}_{2(\mathrm{~d})}$ enters and leaves by diffusive transport. Because phytoplankton were growing at a rate that required a large demand for $\mathrm{CO}_{2(\mathrm{~d})}$, it is reasonable to assume that in spring diatoms may be concentrating $\mathrm{HCO}_{3}{ }^{-}$against a gradient. Implicit in the induction of an active transport system is the requirement for biochemical energy to drive the uptake, either as electron transport coupled to photosynthesis or as ATP (Kaplan et al. 1982, Ogawa et al. 1985). The expense of a DIC-concentrating mechanism can be estimated by calculating the amount of carbon that is actually incorporated into photosynthetic material relative to the DIC pumped in. Sharkey \& Berry (1985) derived a relationship between measured carbon isotope fractionation and the net efflux of DIC:

$$
\Delta=d+b\left(F_{3} / F_{1}\right)
$$

Table 2. Examples of calculations of the $\left[\mathrm{CO}_{2}\right]_{\text {internal }}\left(C_{1}\right)$ to the $\left[\mathrm{CO}_{2}\right]_{\text {external }}\left(C_{\mathrm{d}}\right)$ with the diffusion-model equation presented in Farquher et al. (1982), which assumes the plant is obtaining its $\mathrm{CO}_{2}$ by diffusion. The $c_{d}$ is taken as $20 \mu \mathrm{M}$, a typical value for the lower Delaware Estuary. Productivity values used were averages measured in the 2 regions of the estuary

\begin{tabular}{|c|c|c|c|c|c|c|}
\hline Season & $\begin{array}{l}\text { Phytoplankton } \\
\qquad \delta^{13} \mathrm{C}\end{array}$ & $\begin{array}{c}\Delta \\
(\% \circ)\end{array}$ & $C_{1} / C_{a}$ & $\begin{array}{l}\text { Productivity } \\
\left(\mu \mathrm{M} \subset \mathrm{d}^{-1}\right)\end{array}$ & $\begin{array}{c}C_{!} \\
(\mu \mathrm{M})\end{array}$ & $\begin{array}{l}\text { Residence } \\
\text { time }(d)^{d}\end{array}$ \\
\hline Spring & $-16 \%$ & -4 & 0.10 & 140 & 2.0 & 0.014 \\
\hline Summer & $-30 \%$ & -19 & 0.64 & 110 & 12.8 & 0.116 \\
\hline Fall & $-23 \%$ & -12 & 0.40 & 40 & 8.0 & 0.200 \\
\hline
\end{tabular}




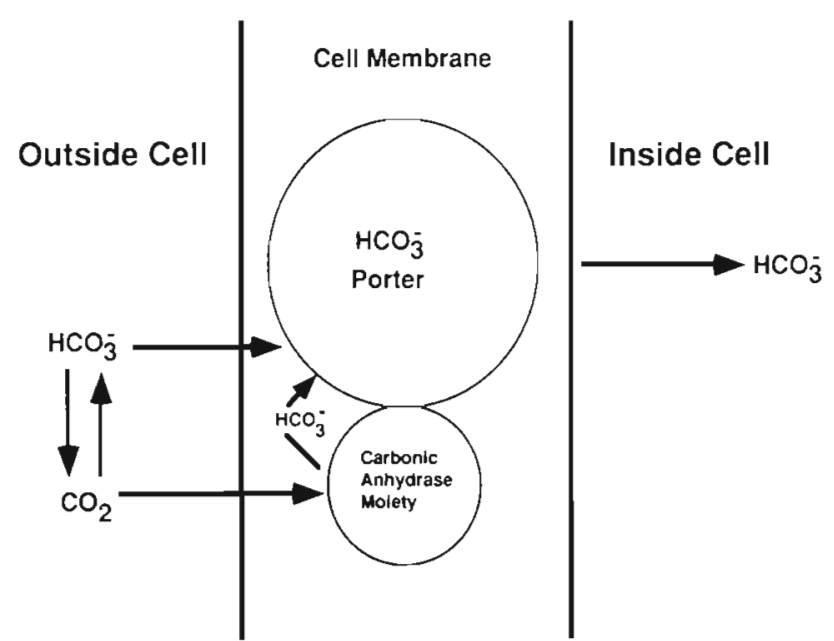

Fig. 5. Diagram of $\mathrm{HCO}_{3}{ }^{-}$or $\mathrm{CO}_{2}$ concentrating mechanisms in plants

where $d=$ the equilibrium isotope fractionation between $\mathrm{HCO}_{3}{ }^{-}$and $\mathrm{CO}_{2(d) ;}$ and $b=$ the isotope fractionation during $\mathrm{CO}_{2}$ fixation by the carboxylase enzymes $\left(27 \%\right.$ ). The term $F_{3} / F_{1}$ is the ratio of $\mathrm{CO}_{2}$ leaking out of the cell $\left(F_{3}\right)$ relative to that transported in $\left(F_{1}\right)$ and is referred to as the leakiness factor. By using this equation, we calculated from our spring isotope fractionation values that ca $59 \%$ of the $\mathrm{HCO}_{3}{ }^{-}$ transported into the cell diffused out before fixation into organic matter (Table 3). This intermediate number between $0 \%$ (minimum energy expenditure and maximal $\left[\mathrm{CO}_{2\{d\}}\right]$ ) and $100 \%$ (maximal energy expenditure and minimal $\left.\left[\mathrm{CO}_{2(\mathrm{~d})}\right]\right)$ implies that photosynthesis is regulated by a balance of $\mathrm{CO}_{2(\mathrm{~d})}$ concentrations and energy utilization.

If a similar situation is postulated for the phytoplankton growing in summer, then by Eq. (4), 96\% of the $\mathrm{HCO}_{3}{ }^{-}$actively transported into the cell would be lost to the water column (Table 3 ). Cells must expend ATP or other biochemical energy to transport $\mathrm{HCO}_{3}{ }^{-}$across the cell membrane (Lucas \& Berry 1985). It seems

Table 3. Calculations of leakiness factors in DIC-concentrating phytoplankton as a function of season. Extreme fractionation values were used for the calculations. NA: not applicable

\begin{tabular}{|llcccc|}
\hline Season & $\begin{array}{l}\text { Carbon species } \\
\text { concentrated }\end{array}$ & $\begin{array}{c}\Delta \\
(\%)\end{array}$ & $\begin{array}{c}d \\
(\% \circ)\end{array}$ & $\begin{array}{c}b \\
(\% \circ)\end{array}$ & $\begin{array}{c}\text { Leakiness } \\
\text { factor }\end{array}$ \\
\hline Spring & $\mathrm{HCO}_{3}{ }^{-}$ & -6 & -10 & 27 & 0.59 \\
Summer & $\mathrm{HCO}_{3}{ }^{-}$ & -18 & -8 & 27 & 0.96 \\
& $\mathrm{CO}_{2 \text { lequilibrium) }}$ & -18 & $\mathrm{NA}$ & 27 & 0.67 \\
& $\mathrm{CO}_{2 \text { (nonequalibrium) }}-13$ & NA & 27 & 0.48 \\
\hline
\end{tabular}

unlikely that organisms would develop this energyintensive strategy for so little gain. An alternative explanation might be that in summer, dominant species of naked flagellates concentrated $\mathrm{CO}_{2(d)}$ rather than bicarbonate. A number of species of algae have been shown to concentrate $\mathrm{CO}_{2(d)}$ in addition to bicarbonate (Lucas \& Berry 1985, Burns \& Beardall 1987; Fig. 5). If so, then the term for the isotopic fractionation between $\mathrm{HCO}_{3}{ }^{-}$and $\mathrm{CO}_{2(\mathrm{~d})}$ drops out of Eq. (4):

$$
\Delta=b\left(F_{3} / F_{1}\right)
$$

Therefore, in summer when the isotopic fractionation was $-18 \%$ and cells presumably transported $\mathrm{CO}_{2(\mathrm{~d})}$, then $67 \%$ of the $\mathrm{CO}_{2(\mathrm{~d})}$ transported in leaked out before fixation.

A second explanation for the difference in $\Delta$ between the 2 seasons could be that $\mathrm{CO}_{2(\mathrm{~d})}$ was not in isotopic equilibrium with the $\mathrm{HCO}_{3}{ }^{-}$pool. In other words, reaction kinetic effects between $\mathrm{CO}_{2(\alpha)}$ and $\mathrm{HCO}_{3}{ }^{-}$have been neglected, in addition to any isotope effects. Heterotrophic activity, which is low during the spring bloom, is maximal in the summer and tracks phytoplankton productivity (Coffin \& Sharp 1987; Kirchman \& Hoch 1988). As a result of the influx of this additional source of $\mathrm{CO}_{2(d)}$ to the water column, the isotopic composition of $\mathrm{CO}_{2(d)}$ may be enriched in ${ }^{12} \mathrm{C}$ originating from particulate organic matter (Fig. 6). For example, the $\delta^{13} \mathrm{C}$ of particulate carbon in the lower bay from the June 1987 cruise that immediately preceded the first July cruise was ca $-25 \%$. Leucine incorporation rates were used to calculate mineralization rates in the water column at this time of the year (Lebo et al. 1990). Peak mineralization by bacteria produced $9 \mu \mathrm{M} \mathrm{C} \mathrm{d}^{-1}$ in July 1987 , when the primary productivity was approximately $100 \mu \mathrm{M} \mathrm{C} \mathrm{d}^{-1}$. An additional source of mineralized $\mathrm{CO}_{2(\mathrm{~d})}$ is usually supplied from respiration by other microheterotrophs and macrozooplankton. In general, respiration by larger organisms is about $30 \%$ of that by bacteria (O'Mori \& Ikeda 1984). Therefore, in the Delaware Estuary in summer, ca $12 \mu \mathrm{M} \mathrm{CO}_{2 \text { (d) }} \mathrm{d}^{-1}$ was released into the water column from mineralization.

To calculate the isotopic composition of $\mathrm{CO}_{2 \text { (d) summer }}$ we assume the isotopic composition of mineralized $\mathrm{CO}_{2(d)}$ was similar to that of the particulate material from which it was derived (Jacobsen et al. 1970). By mass balance:

$$
\begin{aligned}
& \delta^{13} \mathrm{C}_{\mathrm{CO}_{2} \text { summer }}= \\
& f_{1}\left(\delta^{13} \mathrm{C}_{\mathrm{CO}_{2} \text { mineralized }}\right)+f_{2}\left(\delta^{13} \mathrm{C}_{\left.\mathrm{CO}_{2} \text { equilınom }\right)}\right.
\end{aligned}
$$

where $f_{1}=$ the fraction of $\mathrm{CO}_{2(d)}$ derived from mineralized $\mathrm{CO}_{2(d)}$, which is calculated from respiratory inputs; and $f_{2}=$ the fraction of $\mathrm{CO}_{2(d)}$ which is calculated from 


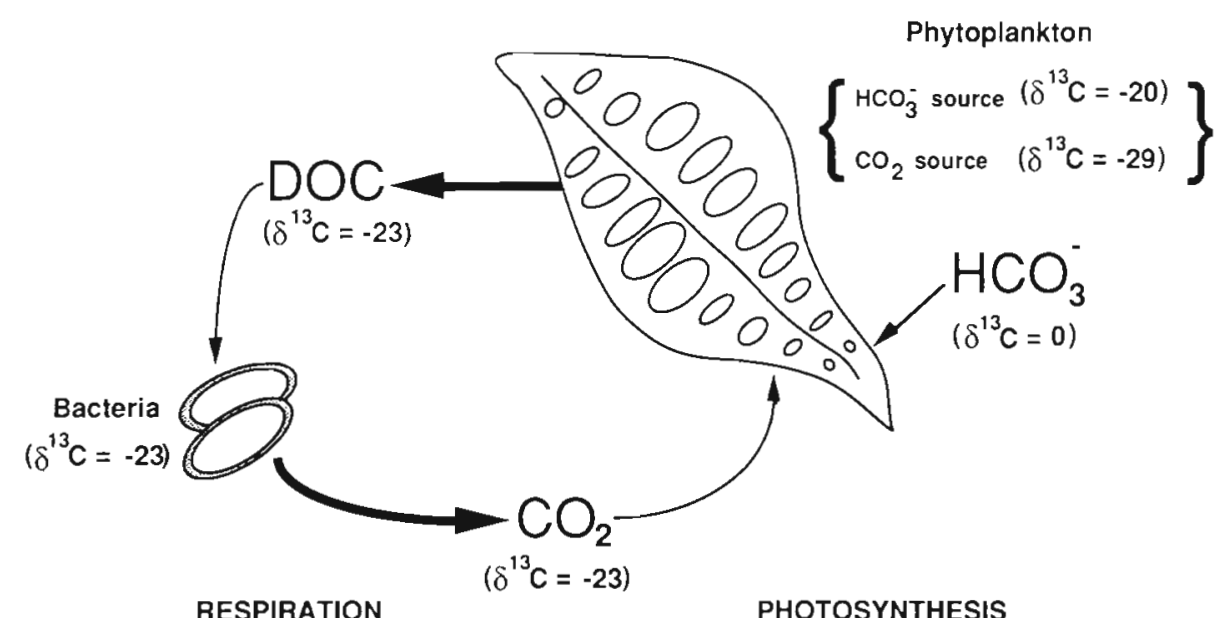

Fig. 6. Conceptual model of the uptake of remineralized $\mathrm{CO}_{2}$ by phytoplankton in summer. Phytoplankton with typical marine $\delta^{13} \mathrm{C}$ values of $-22 \%$ would excrete dissolved organic carbon (DOC) with a similar isotopic composition. Bacteria metabolizing this source of DOC would have similar isotopic compositions. In the process of mineralization, the $\mathrm{CO}_{2(\mathrm{~d})}$ released into the water column by heterotrophs would have a $\delta^{13} \mathrm{C}$ value similar to that of the DOC pool. This respired source of $\mathrm{CO}_{2(\mathrm{~d})}$ would be isotopically lighter than that produced in equilibrium reactions with $\mathrm{HCO}_{3}{ }^{-}$and could be incorporated directly into phytoplankton

DIC measurements with equilibrium constants. With a value of $12 \mu \mathrm{M}$ from respiration and $20 \mu \mathrm{M}$ from DIC concentrations (Table 1 ), the estimated $\delta^{13} \mathrm{C}_{\mathrm{CO}_{2} \text { summer }}$ is several \%o more negative $\left(\delta^{13} \mathrm{C}=-16.5\right)$ than the $\delta^{13} \mathrm{C}$ of $\mathrm{CO}_{2(\mathrm{~d})}$ at equilibrium $\left(\delta^{13} \mathrm{C}=-11.6\right)$.

Accordingly, if $\Delta$ is recalculated relative to this isotopically light respired $\mathrm{CO}_{2(\mathrm{~d})}$, then the leakiness factor of the cells with respect to $\mathrm{CO}_{2(\mathrm{~d})}$ has a value of 0.48 (Table 3 ). The difference in leakiness determined by the 2 calculations may be important in terms of the energy balance of the cell. A $20 \%$ reduction in carbon dioxide leaking from the algal cell means a $20 \%$ savings in photosynthetic energy. Phytoplankton with a DIC-concentrating mechanism must balance their need for $\mathrm{CO}_{2}$ with the need to produce energy for growth, metabolism, and reproduction.

\section{Summary}

Stable carbon isotope ratios and the isotopic fractionations that can be calculated from them can be used to understand availability and sources of $\mathrm{CO}_{2(d)}$ to phytoplankton during conditions of high productivity. In the Delaware Estuary, moderately high productivity in the spring occurs as a bloom with a large accumulation of phytoplankton biomass and relatively low heterotrophic activity. High productivity also takes place in summer, but is sustained by a considerably smaller phytoplankton biomass at a time when heterotrophic activity is maximal (Coffin \& Sharp 1987, Kirchman \& Hoch 1988, Lebo et al. 1990). The range in the $\delta^{13} \mathrm{C}$ values of particulate carbon varied so widely over $1 \mathrm{yr}$ that it was impossible to correlate productivity to changes in isotopic content. Temperature or $\mathrm{CO}_{2(\mathrm{~d})}$ concentrations in the water column also had no direct relationship to $\delta^{13} \mathrm{C}$ of particulate matter. In the cold spring months, with average water temperatures of $8{ }^{\circ} \mathrm{C}$, the $\delta^{13} \mathrm{C}$ values were most positive. This finding contrasts with an explanation by Rau et al. (1989). In that study, the $\delta^{13} \mathrm{C}$ of phytoplankton in the open ocean was related to the concentration of $\mathrm{CO}_{2[\mathrm{~d}] \text {, which was }}$ calculated with temperatures of surface waters, assuming both chemical and isotopic equilibrium of dissolved inorganic carbon species.

Conversely, during the warm summer months in the Delaware when water temperatures often exceeded $22{ }^{\circ} \mathrm{C}$, the most negative isotopic compositions for seston were measured. Evidently, the uptake and fractionation of carbon by phytoplankton is very complex and not simply related to any 1 factor. A physiological mechanism for adequate accumulation of carbon internal to the cell would explain some of the isotopic variations that have been measured. Dissolved inorganic carbon-concentrating mechanisms described in the literature (Lucas \& Berry 1985) have been shown to be operational in marine species of phytoplankton. Small isotopic fractionations calculated in spring in the Delaware would correspond with the transport of $\mathrm{HCO}_{3}$ into the cell and accumulation by the predominant diatom species. The larger, apparent isotopic fractionations calculated in summer would correspond with $\mathrm{CO}_{2(d)}$ uptake and concentration by predominant naked flagellates. Similar differences in carbon isotopic compositions of up to $2.3 \%$ between smaller flagellate species and larger diatom species have been 
measured in Narragansett Bay (Gearing et al. 1984). This isotopic effect which appears to be related to species composition could be explained by different DIC-concentrating mechanisms in different phytoplankton

Acknowledgements. We thank Jonathan Pennock and John Ludlam for the ${ }^{14} \mathrm{C}$-uptake determinations and assistance with sample collection. The work was funded by a grant from the NSF to J.H.S., J. Pennock, and M.L.F. (OCE-8601616). Richard B. Coffin and Paul L. Koch provided critical reviews of the manuscript.

\section{LITERATURE CITED}

Burns, B. D., Beardall, J. (1987). Utilization of inorganic carbon by marine microalgae. J. exp. mar. Biol. Ecol. 107: $75-86$

Carpenter, E. J., Capone, D. G. (1983). Nitrogen in the marine environment. Academic Press, New York

Church, T. M. (1986). Biogeochemical factors influencing the residence time of micro-constituents in a large tidal estuary. Mar. Chem. 18:393-406

Cifuentes, L. A., Fogel, M. L., Pennock, J. R., Sharp, J. H. (1989). Biogeochemical factors that influence the stable nitrogen isotope ratio of dissolved ammonium in the Delaware Estuary. Geochim. cosmochim. Acta 53: 2713-2721

Cifuentes, L. A., Sharp, J. H., Fogel, M. L. (1988). Stable carbon and nitrogen isotope biogeochemistry in the Delaware estuary. Limnol. Oceanogr. 33: 1102-1115

Coffin, R. B., Sharp, J. H. (1987). Microbial trophodynamics in the Delaware Estuary. Mar Ecol. Prog. Ser 41: 253-266

Cooper, T G., Filmer, D., Wishnick, M. Lane, M. D. (1969). The active species of $\mathrm{CO}_{2}$ utilized by ribulose diphosphate carboxylase. J. biol. Chem. 244: 1081-1083

Culberson, C. H. (1988). Dissolved oxygen, inorganic carbon, and the acid-base system in the Delaware Estuary. In: Majumdar, S. K., Miller, E. W., Sage, L. E. (eds.) Ecology and restoration of the Delaware River Basin. Pennsylvania Acad. Sciences, Phillipsburg, NJ, p. 58-76

Eppley, R., Sharp, J. H. (1974). Photosynthetic measurements in the central North Pacific: the dark loss of carbon in 24-h incubations. Limnol. Oceanogr. 20: 981-987

Estep, M. L. F. (1984). Carbon and hydrogen isotopic compositions of algae and bacteria from hydrothermal environments. Geochim cosmochim. Acta 48:591-599

Farquhar, G. D., O'Leary, M. H., Berry, J. A. (1982). On the relationship between carbon isotopic discrimination and the intracellular carbon dioxide concentration in leaves. Aust. J. Plant Physiol 9: 121-137

Fogel, M. L., Velinsky, D. J., Cifuentes, L. A., Pennock, J. R., Sharp, J. H. (1988). Biogeochemical processed affecting the stable carbon isotopic composition of particulate carbon in the Delaware estuary. Ann. Rep. Director Geophys. Lab., Carnegie Inst. Wash. 1987-1988: 107-113

Fry, B., Sherr, E. B. $(1984) \cdot \delta^{13} \mathrm{C}$ measurements as indicators of carbon flow in marine and freshwater ecosystems. Contrib. mar. Sci. 27: 13-47

Gearing, J. N., Gearing, P. J., Rudnick, D. T., Requejo, A. G., Hutchins, M. J. (1984). Isotopic variability of organic carbon in a phytoplankton-based, temperate estuary. Geochim. cosmochim. Acta 48: 1089-1098.
Guy, R. D., Fogel, M. F., Berry, J. A., Hoering, T. C. (1987). Isotope fractionation during oxygen production and consumption by plants. Prog. Photosynthesis Res. 3(9): 597-600

Harvey, H. W. (1938). The supply of iron to diatoms. J. mar. biol, Ass. U.K. 22: 205-219

Hassan, A. A. (1980). Methodologies for extraction of dissolved inorganic carbon isotope studies: evaluation and alternatives. U.S. Geol Survey Water-Resources Investigations 82-6. Reston, VA, p. 1-51

Hecky, R. E., Kilham, P. (1988). Nutrient limitation of phytoplankton in freshwater and marine environments. A review of recent evidence on effects of enrichment. Limnol. Oceanogr. 33: 796-822

Jacobsen, B. S., Smith, B. N., Epstein, S. Laties, G. G. (1970). The prevalence of carbon- 13 in respiratory carbon dioxide as an indicator of the type of endogenous substrate. J. gen. Physiol. 55: 1-17

Kaplan, D., Zenvirth, D., Reinhold, L., Berry, J. A. (1982). Involvement of a primary electrogenic pump in the mechanism for $\mathrm{HCO}_{3}{ }^{-}$uplake by the cyanobacterium Anabaena variabilis. Plant Physiol. 69: 978-982

Kirchman, D. L., Hoch, M. H. (1988). Bacterial production in the Delaware Bay estuary estimated from thymidine and leucine incorporation rates. Mar. Ecol. Prog. Ser. 45: $169-178$

Kroopnick, P., Deuser, W. G., Craig, H., (1970). Carbon 13 measurements on dissolved inorganic carbon at the North Pacific (1969) Geosecs Station. J. geophys. Res. 75: $7668-7671$

Lebo, M. E., Cifuentes, L. A., Fogel, M. L., Hoch, M. P., Keil, R. G., Kirchman, D. L., Ludlam, J. M., Pennock, J. R., Sharp, J. H., Spicer, P. T., Velinsky, D. J. (1990). Data from Delaware estuary SCENIC cruises, April 1986-September 1988. Oceanographic Data Report No. 7 Univ. of Delaware, Newark, p. 139

Lebo, M. E., Sharp, J. H. (1992). Modeling phosphorus cycling in a well-mixed coastal plain estuary. Estuarine coast. Shelf Sci. (in press)

Lewan, M. D. (1986). Stable carbon isotopes of amorphous kerogens from Phanerozoic sedimentary rocks. Geochim. Cosmochim. Acta 50: 1583-1591

Lucas, W. J., Berry, J. A. (1985). Inorganic carbon uptake by aquatic photosynthetic organisms. American Society of Plant Physiology, Rockville, MD

Martin, J. H., Gordon, R. M., Fitzwater, S., Broekow, W. W. (1989). VERTEX: Phytoplankton/iron studies in the Gulf of Alaska. Deep Sea Res. 36: 649-680

Millero, F. J. (1979). The thermodynamics of the carbonate system in seawater. Geochim. cosmochim. Acta 43: 1651-1661

Mook, W. G., Bommerson, J C., Staverman, W. H. (1974). Carbon isotope fractionation between dissolved bicarbonate and gaseous carbon dioxide. Earth planet. Sci. Lett. 22: 169-176

Ogawa, T., Omata, T., Miyano, A, Inoue, Y (1985). Photosynthetic reactions involved in the $\mathrm{CO}_{2}$-concentrating mechanism in the cyanobacterium, Anacystis nidulans. In: Lucas, W. J., Berry, J. A. (eds.) Inorganic carbon uptake by aquatic photosynthetic organisms. American Society of Plant Physiology, Rockville, MD, p. 287-304

O'Leary, M. H. (1988). Carbon isotope fractionation during photosynthesis. BioSci. 38: 328-336

O'Mori, M., Ikeda, T. (1984). Methods in marine zooplankton ecology. Wiley, New York

Pennock, J. R. (1985). Chlorophyll distributions in the Delaware Estuary: regulation by light limitation. Estuar. coast. Shelf Sci. 24: 841-857 
Pennock, J. R., Sharp, J. H. (1986). Phytoplankton production in the Delaware estuary: temporal and spatial variability. Mar. Ecol. Prog. Ser. 34: 143-155

Rau, G. H., Takahashi, T., DesMarais, D. J. (1989). Latitudinal variations in plankton $\delta^{1 .} \mathrm{C}$ : implication for $\mathrm{CO}_{2}$ and productivity in past oceans. Nature, Lond. 341 516-518

Roeske, C. A., O'Leary, M. H. (1984). Carbon isotope effects on the enzyme-catalyzed carboxylation of ribulose bisphosphate. Biochemistry 23: 6275-6284

Ryther, J. H., Dunstan, W. M. (1971). Nitrogen, phosphorus, and eutrophication in the coastal marine environment. Science 171: 1008-1013

Sackett, W. M., Eckelmann, W. R., Bender, M. L., Be, A. W. H. (1964). Temperature dependence of carbon isotope composition in marine plankton and sediments. Science 148: $235-237$

Sharkey, T., Berry, J. A. (1985). Carbon isotope fractionation of algae as influenced by an inducible $\mathrm{CO}_{2}$ concentrating mechanism. In: Lucas, W. J., Berry, J. A. (eds.) Inorganic carbon uptake by aquatic photosynthetic organisms. American Society of Plant Physiology, Rockville, MD, p. $389-402$

Sharp, J. H. (1988). Trends in nutrient concentrations in the Delaware Estuary. In: Majumdar, S. K., Miller, E. W., Sage, L. E. (eds.) Ecology and restoration of the Delaware River Basin. Pennsylvania Acad. Sciences, Phillipsburg, NJ, p. $78-92$

Sharp, J. H., Cifuentes, L. A., Coffin., R. B., Pennock, J R., Wong, K. C. (1986). The influence of river variability on

This article was presented by O. Holm-Hansen, La Jolla, California, USA the circulation, chemistry, and microbiology of the Delaware Estuary. Estuaries 9: 261-269

Sharp, J. H., Culberson, C. H., Church, T M. (1982). The chemistry of the Delaware Estuary. General considerations. Limnol. Oceanogr. 27: 1015-1028

Sharp, J. H., Pennock, J. R., Church, T. M., Tramontano, J. M., Cifuentes, L. A. (1984). The estuarine interaction of nutrients, organics, and metals: a case study in the Delaware Estuary. In: Kennedy, V. S. (ed.) The estuary as a filter. Academic Press, Orlando, Florida, p. 241-258

Skirrow, G. (1975). The dissolved gases - carbon dioxide. In Riley, J. P., Skirrow, G. (eds.) Chemical oceanography, Vol. 2, 2nd edn. Academic Press, New York, p. 1-192

Smith, S. V. (1984). Phosphorous versus nitrogen limitation in the marine environment. Limnol. Oceanogr. 29: 1149-1160

Spiker, E. C., Schemel, L. E. (1979). Distribution and stableisotope composition of carbon in San Francisco Bay. In: San Francisco Bay: the urbanized estuary. Pacific Division of the American Association for the Advancement of Science, San Francisco, p. 143-174

Van, T. K., Haller, W. T. Bowes, G. (1976). Comparison of the photosynthetic characteristics of three submerged aquatic plants. Plant Physiol. 58: 761-768

Vogel, J. C. (1980). Fractionation of the carbon isotopes during photosynthesis. Sitzungsber. Heidelb. Akad. Wiss Math-Naturwiss. K1 3: 111-135

Whitfield, M., Turner, D. R. (1986). The carbon dioxide system in estuaries - an inorganic carbon perspective. Sci. total Envir. 49: 235-255

Manuscript first received: April 25, 1991

Revised version accepted: March 25, 1992 